OPEN ACCESS

Edited by:

Dongsheng Zhou,

Beijing Institute of Microbiology and

Epidemiology, China

Reviewed by:

Thandavarayan Ramamurthy, National Institute of Cholera and

Enteric Diseases (ICMR), India

Hengyi Xu,

Nanchang University, China

Xiao-Hua Zhang,

Ocean University of China, China

*Correspondence:

Biao Kan

kanbiao@icdc.cn

Specialty section:

This article was submitted to

Clinical Microbiology,

a section of the journal

Frontiers in Cellular and

Infection Microbiology

Received: 05 August 2021

Accepted: 12 October 2021

Published: 02 November 2021

Citation:

Zhao S, Zhang J, Li Z, Han Y and Kan B (2021) Enumeration of Viable

Non-Culturable Vibrio cholerae Using

Droplet Digital PCR Combined With

Propidium Monoazide Treatment.

Front. Cell. Infect. Microbiol. 11:753078.

doi: 10.3389/fcimb.2021.753078

\section{Enumeration of Viable Non- Culturable Vibrio cholerae Using Droplet Digital PCR Combined With Propidium Monoazide Treatment}

\author{
Shuo Zhao, Jingyun Zhang, Zhe Li, Yu Han and Biao Kan* \\ State Key Laboratory of Infectious Disease Prevention and Control, National Institute for Communicable Disease Control \\ and Prevention, Chinese Center for Disease Control and Prevention, Beijing, China
}

Many bacterial species, including Vibrio cholerae (the pathogen that causes cholera), enter a physiologically viable but non-culturable (VBNC) state at low temperature or in conditions of low nutrition; this is a survival strategy to resist environmental stress. Identification, detection, and differentiation of VBNC cells and nonviable cells are essential for both microbiological study and disease surveillance/control. Enumeration of VBNC cells requires an accurate method. Traditional counting methods do not allow quantification of VBNC cells because they are not culturable. Morphology-based counting cannot distinguish between live and dead cells. A bacterial cell possesses one copy of the chromosome. Hence, counting single-copy genes on the chromosome is a suitable approach to count bacterial cells. In this study, we developed quantitative PCR-based methods, including real-time quantitative PCR (qPCR) and droplet digital PCR (ddPCR), to enumerate VBNC $V$. cholerae cells by counting the numbers of single-copy genes in samples during VBNC-state development. Propidium monoazide (PMA) treatment was incorporated to distinguish dead cells from viable cells. Both PCR methods could be used to quantify the number of DNA copies/mL and determine the proportion of dead cells (when PMA was used). The methods produced comparable counts using three singlecopy genes (VC1376, thyA, and recA). However, ddPCR showed greater accuracy and sensitivity than $\mathrm{QPCR}$. ddPCR also allows direct counting without the need to establish a standard curve. Our study develops a PMA-ddPCR method as a new tool to quantify VBNC cells of $V$. cholerae. The method can be extended to other bacterial species.

Keywords: viable but non-cultivable state, ddPCR, qPCR, viable cell counting, propidium monoazide, Vibrio cholerae

\section{INTRODUCTION}

Toxigenic Vibrio cholerae, a part of autochthonous aquatic ecosystems, is a reservoir for human infections and a threat to public health globally (Islam et al., 1994; Kaper et al., 1995; Harris et al., 2012). Previous research has shown that $V$. cholerae can enter into a dormant state, also called the viable but non-culturable (VBNC) state (Xu et al., 1982; Oliver, 2010). The first systematic study of 
the VBNC state in V. cholerae serogroup $\mathrm{O} 1$ was reported by $\mathrm{Xu}$ et al. in 1982 (Xu et al., 1982). This state was defined as metabolically active but lacking the ability to reproduce on routine culture media (Oliver, 2005). When exposed to an unfavorable environment (i.e., starvation, low temperature, sub-optimal redox conditions, irradiation and antibiotic pressure), many species of bacteria can enter a VBNC state for long-term survival (Ducret et al., 2014; Pinto et al., 2015; Wu et al., 2016; Zhang et al., 2021). In the laboratory setting, the VBNC state of $V$. cholerae is usually induced by incubation in artificial sea water (ASW) at $4^{\circ} \mathrm{C}$ (Asakura et al., 2007).

Differentiation between $V$. cholerae in the VBNC state and dead cells is challenging, especially in samples from aquatic ecosystems where the cell concentration is low (Davis, 2014). Propidium iodide staining can be combined with the evaluation of cellular integrity by using an electronically programmable single-cell sorter (Caron et al., 1998). Several studies have used Live/Dead stains combined with microscopic examination or flow cytometry to identify VBNC cells (Nebe-von-Caron et al., 2000; Gonzalez-Escalona et al., 2006). However, FCM intermediate state results were poorly characterized and mainly rely on the experience of the operator (Strauber and Muller, 2010; Dong et al., 2020). These methods are limited in use.

Quantitative real-time PCR and real-time LAMP (qLAMP) combined with propidium monoazide treatment (PMA-qPCR and PMA-qLAMP) are methods to detect VBNC cells (Nocker et al., 2006; Cao et al., 2019). PMA can penetrate damaged cell membranes. Intercalation of DNA by PMA inhibits PCR amplification. Thus, PMA-qPCR has become a popular method for distinguishing between live and dead bacteria (Banihashemi et al., 2012; Wu et al., 2015). In our previous study, we found that treatment of $V$. cholerae with $20 \mu \mathrm{M}$ PMA for 20 min was optimal (Wu et al., 2015).

There are extensive guidelines for the selection of reference genes for new qPCR experiments, and preliminary experiments are very important (Bustin et al., 2009). Nevertheless, most qPCR analyses are carried out using only one reference gene. Moreover, PCR efficiency and analytical parameters are frequently omitted from literature reports. A single-copy gene is a housekeeping gene with only one copy in the genome. Averaging data for three single-copy genes is recommended for qPCR analyses.

The droplet digital polymerase chain reaction (ddPCR) is a unique method for quantifying the absolute copy number of a target gene without external criteria (Sun and Joyce, 2017; Li et al., 2018), i.e., ddPCR does not require a standard curve for quantification. In ddPCR, DNA samples are divided into large water-in-oil droplets and then amplified by PCR. Droplets are then individually analyzed by a fluorescence detector, enabling quantification of the target DNA. This method has higher sensitivity than qPCR (Sun and Joyce, 2017; Link-Lenczowska et al., 2018), and ddPCR is superior to qPCR in accuracy in detecting plasmid-borne genes (Xu et al., 2021). ddPCR data correlates well with qPCR data (Li et al., 2014; Gobert et al., 2018). Analysis of stably-expressed single-copy genes by ddPCR may produce high-quality data, even when a low number of replicates is assayed or the sample is VBNC cells. PMA treatment combined with ddPCR analysis (PMA-ddPCR) has been adopted for quantification of bacterial survival in fecal samples (Gobert et al., 2018).

In this work, we developed a method based on PMA-ddPCR to quantify VBNC cells using VC1376 (encoding GGDEF family protein), thy A (encoding thymidylate synthase), and $\operatorname{rec} A$ (encoding ATP-binding protein Uup), which are all singlecopy genes in $V$. cholerae. We compared the data from ddPCR with that obtained by qPCR. Our results show that ddPCR of single-copy genes combined with PMA treatment is a practical and effective approach for counting VBNC $V$. cholerae cells.

\section{MATERIALS AND METHODS}

\section{Bacterial Strain and Culture Conditions}

$V$. cholerae $\mathrm{O} 1 \mathrm{El}$ Tor strain $\mathrm{C} 6706$ is toxigenic, which is preserved in our laboratory. We performed the experiments with C6706 in our biosafety level 2 (BSL-2) laboratory with the corresponding biosafety protection measures. This strain was initially stored in $20 \%(\mathrm{v} / \mathrm{v})$ glycerol at $-80^{\circ} \mathrm{C}$, then cultured on nutrient agar. Three single colonies of the strain were picked and suspended in Luria-Bertani (LB) broth (Oxoid, Basingstoke, UK) and cultured overnight at $37^{\circ} \mathrm{C}$ with shaking $(200 \mathrm{rpm})$. The cultures were then diluted into fresh LB broth $(1: 50, \mathrm{v} / \mathrm{v})$, incubated at $37^{\circ} \mathrm{C}$ with shaking at $200 \mathrm{rpm}$, and grown to midexponential phase. The cultures were then washed twice with ASW and diluted to $\mathrm{OD}_{600}=1.0$ [approximately $1 \times 10^{9}$ colonyforming units $(\mathrm{CFU}) / \mathrm{mL}$ ]. Finally, the cultures were inoculated into ASW at a final concentration of $1.3 \times 10^{7} \mathrm{CFU} / \mathrm{mL}$. ASW was prepared using sea salt (40 g/L; Sigma-Aldrich, Inc., St. Louis, $\mathrm{MO}$, USA) and was sterilized using $0.22-\mu \mathrm{m}$ membrane filters (Millipore, USA). ASW was used for the culture of $V$. cholerae to simulate the natural environment of $V$. cholerae, to study the VBNC state development of it. LB medium is prepared according to the common formula, for the laboratory culture of $V$. cholerae.

\section{Induction of VBNC State}

Exponential-phase cells were kept in ASW at $4^{\circ} \mathrm{C}$ with oxygen limitation, achieved by filling $2-\mathrm{mL}$ vials to the brim with culture and closing the lid to exclude air. Three vials for each target gene as parallel were used for detection $V$. cholerae. Fresh vial was used for enumeration, and then that culture was discarded to prevent aeration.

\section{PMA Treatment}

As described in our previous study (Wu et al., 2015), viable cells were enumerated using PMA (Biotium, USA) combined with qPCR or ddPCR. Briefly, 200- $\mu \mathrm{L}$ aliquots of cells kept at $4^{\circ} \mathrm{C}$ were treated with $20 \mathrm{mM}$ PMA for $20 \mathrm{~min}$ in the dark, then exposed to light on ice for $15 \mathrm{~min}$ using a 650-W double-ended halogen lamp.

\section{DNA Isolation}

DNA was isolated from $200-\mu \mathrm{L}$ cell suspensions treated or not treated with PMA using a Wizard Genomic DNA Purification 
Kit (Promega, Madison, WI, USA) according to the manufacturer's instructions. To obtain the maximum yield of DNA, a double elution was performed, using $200 \mu \mathrm{L}$ of elution buffer each time. Purified DNA was quantified using a NanoDrop 2000c spectrophotometer (Thermo Scientific, Asheville, NC, USA). DNA samples were stored at $-20^{\circ} \mathrm{C}$.

\section{qPCR Analysis and Standard Curve}

The mixture for qPCR amplification contained $1 \mu \mathrm{L}$ of template DNA, Premix Ex Taq (TaKaRa, Dalian, China), $0.25 \mu \mathrm{M}$ of each forward and reverse primer targeting the single-copy gene VC1376, thy A, or recA of $V$. cholerae O1 (Table 1), and ultrapure water to a final volume of $20 \mu \mathrm{L}$. qPCR was performed in a LightCycler 96 system (Roche, Indianapolis, IN, USA). All qPCR reactions were performed in triplicate. The thermal cycling conditions were: $3 \mathrm{~min}$ at $95^{\circ} \mathrm{C}$; followed by 40 cycles of $5 \mathrm{~s}$ at $95^{\circ} \mathrm{C}$ and $30 \mathrm{~s}$ at $50^{\circ} \mathrm{C}$ for $\mathrm{VC} 1376,54^{\circ} \mathrm{C}$ for thy $A$, and $55^{\circ} \mathrm{C}$ for $\operatorname{rec} A$; then melt curve analysis from $65^{\circ} \mathrm{C}$ to $95^{\circ} \mathrm{C}$ with increments of $0.5^{\circ} \mathrm{C}$ for $5 \mathrm{~s}$ each. The enumeration results were considered negative if the $\mathrm{Cq}$ value was $>36$.

To prepare standard curves, DNA was extracted from purified $V$. cholerae $\mathrm{O} 1 \mathrm{El}$ Tor strain C6706, and the standard curves were made by serially diluting this DNA.

\section{ddPCR Analysis}

EvaGreen ${ }^{\circledR}$ chemistry-based ddPCR and data analysis was performed according to the manufacturer's instructions; EvaGreen Supermix $(2 \times)$ was purchased from Bio-Rad Laboratories. PCR was performed in a $20-\mu \mathrm{L}$ volume containing $10 \mathrm{~mL} 2 \times$ EvaGreen Supermix, $1 \mathrm{~mL}$ DNA, $0.2 \mu \mathrm{M}$ of each primer, and $8.8 \mu \mathrm{L} \mathrm{ddH}_{2} \mathrm{O}$. For negative controls, $5 \mu \mathrm{L}$ water were added instead of genomic DNA. Each sample was quantified twice. A Bio-Rad Automated Droplet Generator was used to generate droplets. Thermal cycling was performed using a Bio-Rad C1000 Touch $^{\mathrm{TM}}$ Thermal Cycler, with conditions: $95^{\circ} \mathrm{C}$ for $5 \mathrm{~min} ; 40 \mathrm{cycles}$ of $30 \mathrm{~s}$ at $95^{\circ} \mathrm{C}$ and $30 \mathrm{~s}$ at $50^{\circ} \mathrm{C}$ for $\mathrm{VC} 1376$, $54^{\circ} \mathrm{C}$ for thy $A$, and $55^{\circ} \mathrm{C}$ for $r e c A$; and a final incubation $4^{\circ} \mathrm{C}$ for $5 \mathrm{~min}$ and $90^{\circ} \mathrm{C}$ for $5 \mathrm{~min}$. After reaction, droplets were analyzed using a QX200 ${ }^{\mathrm{TM}}$ Droplet reader. Data analysis was done using Bio-Rad QuantaSoft ${ }^{\text {TM }}$ software.

\section{Live/Dead Staining}

Live/Dead staining was performed as described previously (Almagro-Moreno et al., 2015). We centrifuged $1 \mathrm{~mL}$ aliquots from each sample at $2152 \times g$ for $2 \mathrm{~min}$, and the pellet was resuspended in $1 \mathrm{~mL}$ phosphate-buffered saline. The cells were then stained with a $3-\mu \mathrm{L}$ mixture of SYTO9 and propidium iodide (1:1 v:v; Molecular Probes, Eugene, OR, USA) per $1 \mathrm{~mL}$ of suspension. After incubation in the dark for $15 \mathrm{~min}$ at $25^{\circ} \mathrm{C}$, the stained cells were mounted on a glass slide and low-fluorescence immersion oil was added on the coverslip. The cells were then examined with a Nikon ECLIPES 80i microscope. Images were captured with NIS-Elements F3.2 microscopy software (Nikon).

\section{Statistical Analysis}

Figures were drawn using GraphPad Prism software from three replicate values. Each replicate value was the mean value from a triplet measurement.

\section{RESULTS}

\section{Sensitivity of qPCR and ddPCR Quantification}

First, we determined the sensitivity of the qPCR and ddPCR assays for $V$. cholerae genes. The average concentration of the $V$. cholerae strain $\mathrm{C} 6706$ cells used (culture at $37^{\circ} \mathrm{C}$ with shaking at $200 \mathrm{rpm}$, to mid-exponential phase) was around $1.3 \times 10^{7} \mathrm{CFU} /$ $\mathrm{mL}$, as determined by plate counting. Chromosomal DNA extracted from $V$. cholerae strain C6706 was used as the template for amplification, at $10 \mathrm{ng} / \mu \mathrm{L}$ to $1 \mathrm{fg} / \mu \mathrm{L}$ (prepared by serial 10 -fold dilution).

Standard curves for quantification of the target genes VC1376, thy $A$, and $r e c A$ by qPCR were constructed in the range $1.3 \times 10^{1}$ to $1.3 \times 10^{5}$ copies $/ \mu \mathrm{L}$ of $\mathrm{C} 6706 \mathrm{DNA}$. The slopes were $-3.26,-3.23$, and -3.34 for $\mathrm{VC1376}$, thyA, and $r e c A$, respectively. The mean qPCR efficiencies for VC1376, thy A, and recA were 99\%, 100\%, and $103 \%$, respectively. The lower limit of detection using SYBR Green (tested in triplicate) was $10 \mathrm{fg} / \mu \mathrm{L}$ of total DNA, with mean Cq values of $35.58 \pm 0.24,35.02 \pm 0.96$, and $34.06 \pm 0.61$ for $\mathrm{VC1376}$, thyA, and recA, respectively (Table 2).

To determine the lower limit of detection by ddPCR, six replicates were performed with the three single-copy genes used to construct the qPCR standard curves. High linearity was observed. With $10 \mathrm{fg} / \mu \mathrm{L}$ of total DNA, a mean of $0.17 \pm 0.03$, $0.22 \pm 0.02$, and $0.27 \pm 0.02$ copies/ $\mu \mathrm{L}$ of $\mathrm{VC} 1376$, thyA, and recA were detected, respectively. Moreover, the detection sensitivity reached $\leq 1$ fg of total DNA $(0.03 \pm 0.02,0.07 \pm 0.01$, and $0.08 \pm$ 0.02 copies $/ \mu \mathrm{L}$, respectively) (Table 2 ). Therefore, ddPCR was 10 times more sensitive than qPCR. Fluorescence-labeled curve reaction saturation of $\mathrm{ddPCR}$ was reached at $100 \mathrm{pg} / \mu \mathrm{L}$ (i.e., $>20,000$ positive droplets).

TABLE 1 | Oligonucleotides used in this study.

\begin{tabular}{lll}
\hline Primer & \multicolumn{1}{c}{ Sequence (5'-3') } & References \\
\hline VC1376-F & TAACATAATAAGGAAGAAGTGGAT & Wu et al., 2015 \\
VC1376-R & ACAGTCAGAAGCAGAGAA & This study \\
thyA-F & ACATGGGACGCGTGTATGG & \\
thyA-R & ATATGACCACCATCAGGCTTAGC & Kotetishvili et al., 2003 \\
RecA-F & GTGCTGTGGATGTCATCGTTGTTG \\
RecA-R & CCACCACTTCTTCGCCTTCTTGA
\end{tabular}


TABLE 2 | Gene quantification (VC1376, thyA, and recA) by qPCR and ddPCR from a 10-fold serial dilution of genomic DNA of V. cholerae strain C6706.

\begin{tabular}{|c|c|c|c|c|c|c|}
\hline \multicolumn{7}{|c|}{ qPCR } \\
\hline \multirow[t]{2}{*}{ Concentration of Template } & \multicolumn{2}{|c|}{ VC1376 } & \multicolumn{2}{|c|}{ thyA } & \multicolumn{2}{|c|}{$\operatorname{rec} A$} \\
\hline & Cq mean & SD & Cq mean & SD & Cq mean & SD \\
\hline $10 \mathrm{ng} / \mu \mathrm{L}$ & 16.11 & 0.08 & 16.73 & 0.16 & 14.17 & 0.11 \\
\hline $100 \mathrm{pg} / \mu \mathrm{L}$ & 23.21 & 0.08 & 23.48 & 0.17 & 21.27 & 0.12 \\
\hline 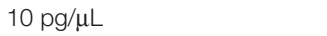 & 26.93 & 0.10 & 27.18 & 0.19 & 25.01 & 0.18 \\
\hline $1 \mathrm{pg} / \mu \mathrm{L}$ & 29.71 & 0.15 & 30.25 & 0.21 & 27.90 & 0.48 \\
\hline $100 \mathrm{fg} / \mu \mathrm{L}$ & 32.64 & 0.45 & 32.33 & 0.86 & 31.52 & 0.64 \\
\hline $10 \mathrm{fg} / \mu \mathrm{L}$ & 35.58 & 0.24 & 35.02 & 0.96 & 34.06 & 0.61 \\
\hline $1 \mathrm{fg} / \mu \mathrm{L}$ & UD & UD & UD & UD & UD & UD \\
\hline $\mathrm{R}^{2}$ & 0.997 & & 0.995 & & 0.999 & \\
\hline \multicolumn{7}{|c|}{ ddPCR } \\
\hline \multirow{2}{*}{$\begin{array}{l}\text { Concentration of } \\
\text { Template }\end{array}$} & \multicolumn{2}{|c|}{ VC1376 } & \multicolumn{2}{|c|}{ thyA } & \multicolumn{2}{|c|}{ recA } \\
\hline & copies $/ \mu L^{*}$ & SD & copies $/ \mu L^{*}$ & SD & copies $/ \mu L^{*}$ & SD \\
\hline 10 ng/ $\mu \mathrm{L}$ & ULOD & ULOD & ULOD & ULOD & ULOD & ULOD \\
\hline 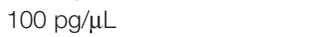 & 913.00 & 18.38 & 1253.00 & 16.97 & 711.50 & 19.09 \\
\hline 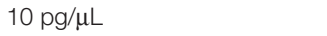 & 118.00 & 7.07 & 119.50 & 9.19 & 64.30 & 12.30 \\
\hline $1 \mathrm{pg} / \mu \mathrm{L}$ & 10.70 & 0.71 & 11.45 & 0.92 & 8.65 & 0.49 \\
\hline $100 \mathrm{fg} / \mu \mathrm{L}$ & 1.20 & 0.14 & 1.60 & 0.42 & 1.45 & 0.21 \\
\hline $10 \mathrm{fg} / \mu \mathrm{L}$ & 0.17 & 0.03 & 0.22 & 0.02 & 0.27 & 0.02 \\
\hline $1 \mathrm{fg} / \mu \mathrm{L}$ & 0.03 & 0.02 & 0.07 & 0.01 & 0.08 & 0.02 \\
\hline $\mathrm{R}^{2}$ & 0.997 & & 0.992 & & 0.999 & \\
\hline
\end{tabular}

*The amount of DNA in each reaction.

$U D$, undetected. ULOD, DNA concentration at which the signal of the assay was saturated (>20,000 copies in the reaction mixture).

Both PCR methods showed good linearity in the range of quantification, with $\mathrm{R}^{2}$ values between 0.992 and 0.999 for the three genes. The number of DNA copies/ $\mu \mathrm{L}$ in samples not treated with PMA determined using genes VC1376, thyA, and recA was similar using either qPCR or ddPCR.

\section{Enumeration of VBNC Cells by qPCR and ddPCR}

Both qPCR and ddPCR methods were used to quantify DNA copies from VBNC-state cells; samples were taken on day 70 of the VBNC-state development of $V$. cholerae strain C6706. All three genes (VC1376, thyA, and recA) were used as targets for enumeration. Total VBNC cells and VBNC-state living cells were enumerated by PCR without or with PMA treatment (Figure 1). We report the enumeration of cells per $\mathrm{mL}$ in terms of the number of DNA copies of the three genes per $\mathrm{mL}$ (noting that there is one copy of each gene per cell).

Similar numbers of total cells (i.e., live + dead) were determined by ddPCR using VC1376 and recA $(6.18 \pm 0.10$ and $6.20 \pm 0.19 \log _{10}$ DNA copies/mL, respectively), and slightly higher values were determined using thyA $\left(6.29 \pm 0.13 \log _{10}\right.$ DNA copies $/ \mathrm{mL}$ ). Quantification of viable cells by ddPCR gave values $5.4 \pm 0.06$ and $5.39 \pm 0.16 \log _{10}$ DNA copies/mL using VC1376 and thyA respectively; a slightly higher value was determined using recA $\left(5.55 \pm 0.10 \log _{10}\right.$ DNA copies $\left./ \mathrm{mL}\right)$.

The loss of cellular viability was evaluated from the cell counts determined by qPCR or ddPCR and the counts determined by PMA-qPCR or PMA-ddPCR, respectively. Using qPCR, the viability loss determined using $\mathrm{VC1376}$, thyA, and recA was $0.7,0.58$, and $1.13 \log _{10}$ DNA copies $/ \mathrm{mL}$, respectively. Using
ddPCR, the viability loss determined using VC1376, thyA, and recA was $0.78,0.74$, and $0.81 \log _{10} \mathrm{DNA}$ copies $/ \mathrm{mL}$, respectively.

The consistency of the ddPCR-derived data was better than that obtained by $\mathrm{qPCR}$ when tested with samples from day 70 of

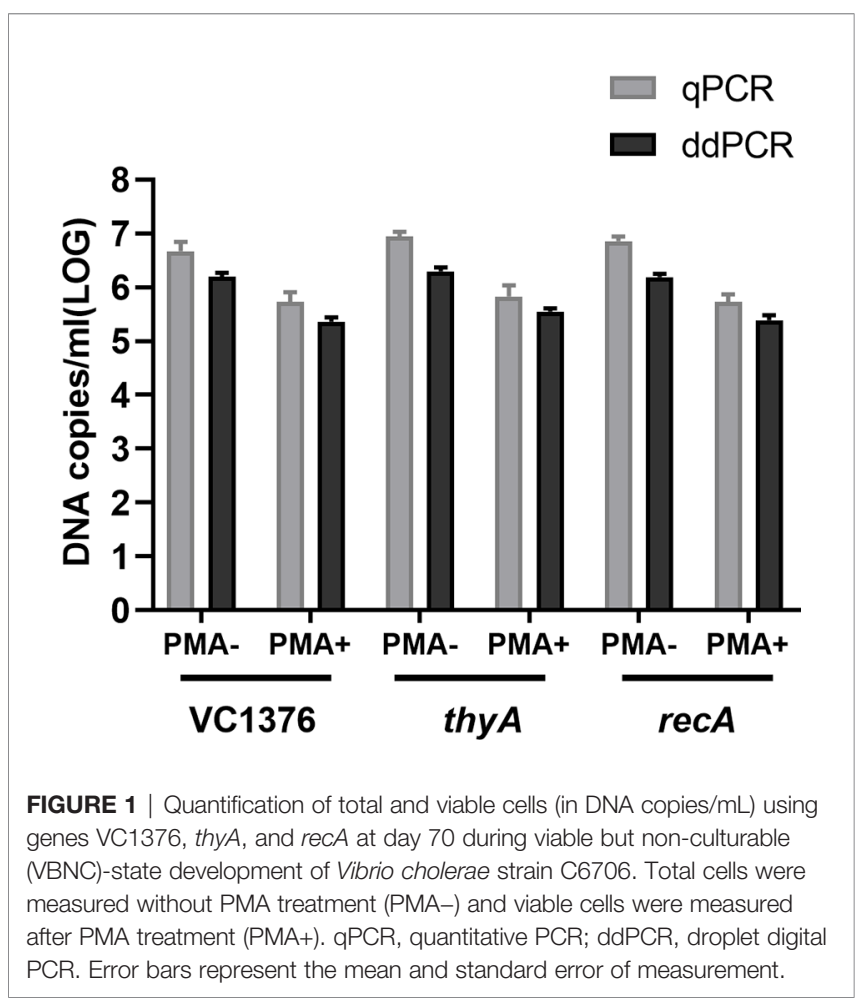


VBNC-state development (Table 3). Here we calculated the proportion of VBNC-state cells using the absolute value of live cells (DNA copies/mL in samples with PMA treatment) and the total number of DNA copies/mL (samples without PMA treatment). Quantification of the VBNC cell proportion by qPCR was $13.09 \%, 38.91 \%$, and $9.30 \%$ when determined using VC1376, thyA, and recA, respectively, showing low consistency of the data produced using these test genes. However, when measured using ddPCR, the VBNC cell proportions were $16.09 \%, 18.06 \%$, and $15.61 \%$ for $\mathrm{VC} 1376$, thyA, and recA, respectively.

\section{Quantification of Viable Cells During VBNC-State Development}

Development of the VBNC state of $V$. cholerae is a process. Day 70 was the endpoint of observation of the VBNC state in our study. Culture samples with and without PMA treatment were collected on days $0,10,20,30$ and 70. Cellular DNA was extracted and determined by qPCR and ddPCR. The culturable cell counts (determined on LB-agar plates) decreased gradually and fell to zero after 30 days (Figure 2A). Viable cell counts were confirmed by Live/Dead staining, PMA-qPCR, and PMA-ddPCR (Figure 2). The viable cell counts determined by PMA-qPCR and PMA-ddPCR using VC1376, thyA, and recA showed a slow decrease from day 0 to day 70 , from $6.09-7.01 \log _{10}$ DNA copies/ $\mathrm{mL}$ to $5.21-6.23 \log _{10}$ DNA copies/mL (Figures 2E, F). Based on the data presented in Figuers 2B-F, a slightly lower count of DNA copies/mL was determined by PMA-ddPCR than by PMA-qPCR at each time point and for each gene, and the values obtained by qPCR had higher variance than the ddPCR data. Therefore, ddPCR had higher repeatability than qPCR in the counting of gene copies.

\section{DISCUSSION}

Development of the VBNC state of bacteria progresses with loss of culturability but preservation of viability (Trevors, 2011). Therefore, viable cell counts and culturable cell counts are the main indicators to reflect the progress of development of the VBNC state. Differentiation of VBNC-state $V$. cholerae from dead cells is challenging, especially in environmental samples (Davis, 2014). The reference methods used to identify the presence of $V$. cholerae are mostly culture-based; as VBNC cells cannot, by definition, be cultured, alternative methods must be developed to count VBNC cells. Methods based on cellular activity, the exploitation of physiological responsiveness (Kogure et al., 1979), and nucleic acid synthesis (Lleo et al., 2000) can be used to qualitatively detect viable cells. Each viable cell has an intact membrane and one copy of the chromosomal DNA, which may allow enumeration of VBNC cells by counting singlecopy genes in the chromosomal DNA. In this study, we evaluated the use of PMA-ddPCR to quantify $V$. cholerae VBNC cells, and compared the data with that obtained by PMA-qPCR.

One major difference between qPCR and ddPCR quantification was the minimum positive copy number. While qPCR was not precise below $10 \mathrm{fg} / \mu \mathrm{L}$ of total DNA, the detection limit of ddPCR was $1 \mathrm{fg} / \mu \mathrm{L}$ of total DNA. This difference was of particular importance-ddPCR can be used to determine accurate results with a low number of VBNC cells. Thus, VBNC cells could be quantified in more samples (e.g., of environmental waters) by ddPCR. The inability to use qPCR to accurately quantify low numbers of VBNC cells has been reported previously (Lahteinen et al., 2014), and the greater capability of ddPCR to quantify small amounts of target molecules compared with qPCR is also in agreement with literature data (Gobert, et al., 2018; Xu et al., 2021).

In this study, we selected three single-copy genes to evaluate the counting of VBNC cells. One purpose of this was to use these genes for parallel verification of the quantitative PCR methods in gene copy counting; another was to compare results when testing with different genes using different primers and probes. Both qPCR and ddPCR, used in parallel, were successful for quantification of DNA copies in total and viable cells using VC1376, thyA, and recA as the target genes. The slight difference in the mean $\mathrm{Cq}$ values for the three genes probably resulted from different qPCR efficiencies of the primers, but the Cq values were similar, validating the method. However, the DNA copy numbers measured by qPCR had wider confidence intervals than those determined by dAPCR at each time point during development of the VBNC state, probably because ddPCR is an absolute counting method whereas $\mathrm{qPCR}$ relies on the amplification efficiency, $\mathrm{Cq}$ value, and calculation based on reference values. It was found that the DNA copy enumeration from the three genes by the two PCR methods was different (for example, the VBNC cell proportions and viability loss rates at day 70 of VBNC-state development were different), probably because of different amplification efficiencies. We found that quite similar gene copy enumeration was obtained when using genes VC1376, thy A, and recA, suggesting that these genes and the primers tested in this study can be used in the enumeration of VBNC cells.

TABLE 3 | Assessment of viability loss rate of V. cholerae strain C6706 on day 70 of VBNC-state development by quantification of VC1376, thyA, and recA by qPCR and ddPCR.

\begin{tabular}{|c|c|c|c|}
\hline Gene & Method & VBNC rate & Viability loss rate \\
\hline \multirow[t]{2}{*}{ VC1376 } & qPCR & $13.09 \%$ & $86.91 \%$ \\
\hline & ddPCR & $16.09 \%$ & $83.91 \%$ \\
\hline \multirow[t]{2}{*}{ thyA } & qPCR & $38.91 \%$ & $61.09 \%$ \\
\hline & ddPCR & $18.06 \%$ & $81.94 \%$ \\
\hline \multirow[t]{2}{*}{ recA } & qPCR & $9.30 \%$ & $90.7 \%$ \\
\hline & ddPCR & $15.61 \%$ & $84.39 \%$ \\
\hline
\end{tabular}




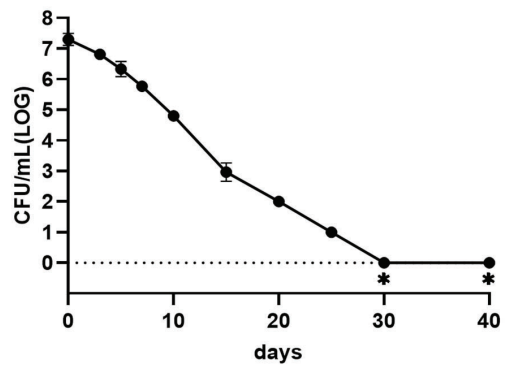

C
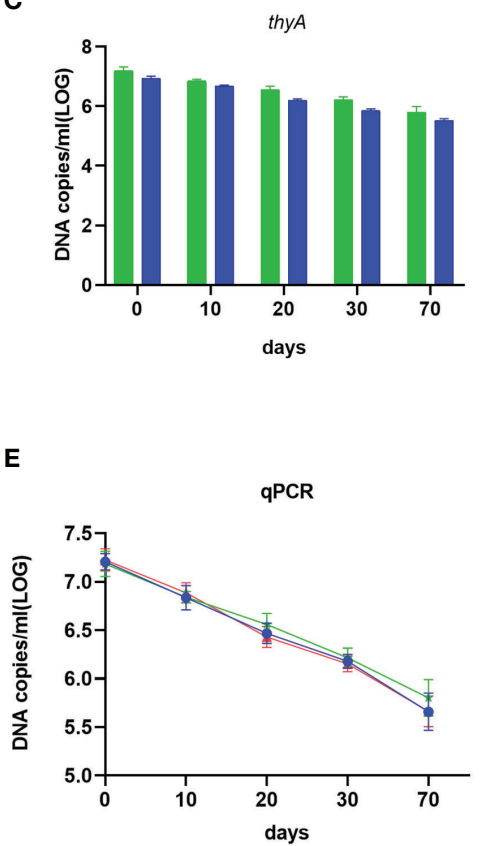

B

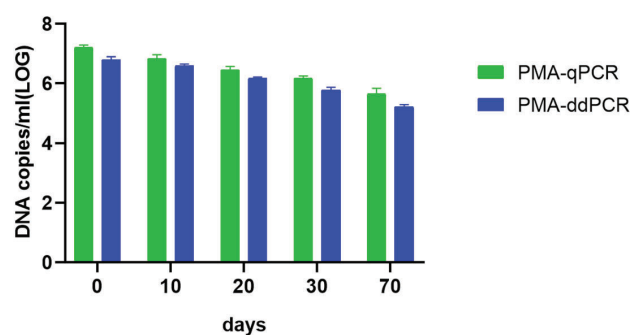

D

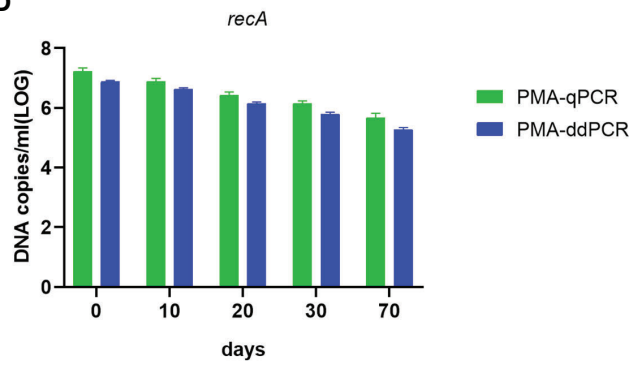

F

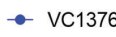

* thyA

$\star r e c A$

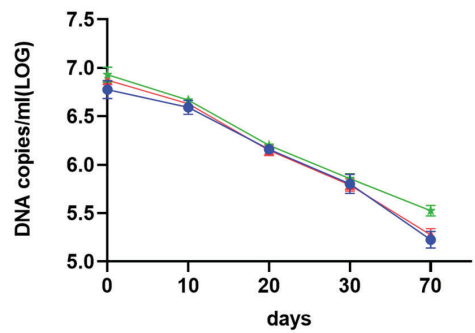

- VC1376

* thy A

$\star$ recA

G

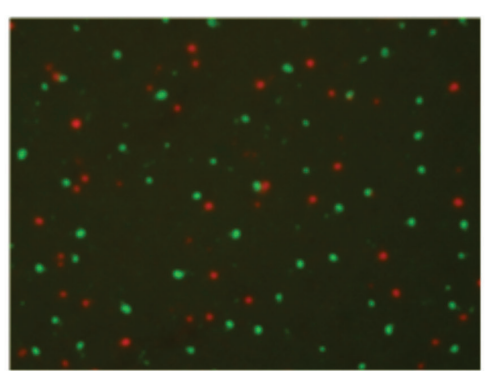

FIGURE 2 | Enumeration of viable cells by qPCR and ddPCR during VBNC-state development of $V$. cholerae strain C6706. (A) Culturable cell counts during VBNCstate development of strain C6706. $*$ indicates that the culturable cell count was $<1$ colony-forming unit/mL. (B-D) DNA copies/mL measured using genes VC1376, thy A and recA after PMA treatment. (E, F) Change in number of DNA copies/mL measured by GPCR or ddPCR for determination of viable cell counts during VBNCstate development. (G) Live/Dead staining of cells of $V$. cholerae strain C6706 on day 70 of VBNC-state development. Viable cells, which are stained only by SYTO9, appear green; dead bacteria appear red.

This method has potential applications for identification the viable pathogens or other studies bacteria in samples, which cannot be conventionally cultured but still exist in VBNC state. Such as, it can be used in the distinguishment of dead and unculturable but alive bacteria in patient or food samples; or in the risk assessment of $V$. cholerae or other pathogens in the environment water, since the common culture methods cannot obtain the pathogen in VBNC state. In summary, we established and evaluated quantitative PCR-based methods to count viable but unculturable cells of $V$. cholerae, by counting single-copy 
chromosomal genes of VBNC-state cells. Treatment with PMA effectively excluded the chromosomal DNA of dead cells. ddPCR combined with PMA treatment was better for VBNC cell counting than qPCR, and can be used in VBNC-state research, and detection and surveillance of VBNC-state cells of $V$. cholerae in the environment. This approach could also be extended to other bacterial species.

\section{DATA AVAILABILITY STATEMENT}

The raw data supporting the conclusions of this article will be made available by the authors, without undue reservation.

\section{REFERENCES}

Almagro-Moreno, S., Kim, T. K., Skorupski, K., and Taylor, R. K. (2015). Proteolysis of Virulence Regulator ToxR Is Associated With Entry of Vibrio cholerae Into a Dormant State. PLoS Genet. 7, 11. doi: 10.1371/journal. pgen.1005145

Asakura, H., Ishiwa, A., Arakawa, E., Makino, S., Okada, Y., Yamamoto, S., et al. (2007). Gene Expression Profile of Vibrio cholerae in the Cold Stress Induced Viable But Non-Culturable State. Environ. Microbiol. 9, 869-879. doi: 10.1111/ j.1462-2920.2006.01206.x

Banihashemi, A., Van Dyke, M. I., and Huck, P. M. (2012). Long-Amplicon Propidium Monoazide PCR Enumeration Assay to Detect Viable Campylobacter and Salmonella. J. Appl. Microbiol. 113, 863-873. doi: 10.1111/j.1365-2672.2012.05382.x

Bustin, S. A., Benes, V., Garson, J. A., Hellemans, J., Huggett, J., Kubista, M., et al. (2009). The MIQE Guidelines: Minimum Information for Publication of Quantitative Real-Time PCR Experiments. Clin. Chem. 55, 611-622. doi: 10.1373/clinchem.2008.112797

Cao, X., Zhao, L. C., Zhang, J. F., Chen, X., Shi, L., Fang, X., et al. (2019). Detection of Viable But Nonculturable Vibrio parahaemolyticus in Shrimp Samples Using Improved Real-Time PCR and Real-Time LAMP Methods. Food Control. 103, 145-152. doi: 10.1016/j.foodcont.2019.04.003

Caron, G. N., Stephens, P., and Badley, R. A. (1998). Assessment of Bacterial Viability Status by Flow Cytometry and Single Cell Sorting. J. Appl. Microbiol. 84, 988-998. doi: 10.1046/j.1365-2672.1998.00436.x

Davis, C. (2014). Enumeration of Probiotic Strains: Review of Culture-Dependent and Alternative Techniques to Quantify Viable Bacteria. J. Microbiol. Methods 103, 9-17. doi: 10.1016/j.mimet.2014.04.012

Dong, K., Pan, H., Yang, D., Rao, L., Zhao, L., Wang, Y. T., et al. (2020). Induction, Detection, Formation, and Resuscitation of Viable But Non-Culturable State Microorganisms. Compr. Rev. Food Sci. Food Saf. 19, 149-183. doi: 10.1111/ 1541-4337.12513

Ducret, A., Chabalier, M., and Dukan, S. (2014). Characterization and Resuscitation of 'Nonculturable' Cells of Legionella pneumophila. BMC Microbiol. 14, 3. doi: 10.1186/1471-2180-14-3

Gobert, G., Cotillard, A., Fourmestraux, C., Pruvost, L., Miguet, J., and Boyer, M. (2018). Droplet Digital PCR Improves Absolute Quantification of Viable Lactic Acid Bacteria in Faecal Samples. J. Microbiol. Methods 148, 64-73. doi: 10.1016/j.mimet.2018.03.004

Gonzalez-Escalona, N., Fey, A., Hofle, M. G., Espejo, R. T., and Guzmán, A. G. (2006). Quantitative Reverse Transcription Polymerase Chain Reaction Analysis of Vibrio cholerae Cells Entering the Viable But Non-Culturable State and Starvation in Response to Cold Shock. Environ. Microbiol 8, 658-666. doi: 10.1111/j.1462-2920.2005.00943.x

Harris, J. B., LaRocque, R. C., Qadri, F., Ryan, E. T., and Calderwood, S. B. (2012). Cholera. Lancet 379, 2466-2476. doi: 10.1016/S0140-6736(12)60436-X

Islam, M. S., Drasar, B. S., and Sack, R. B. (1994). The Aquatic Flora and Fauna as Reservoirs of Vibrio cholerae: A Review. J. Diarrhoeal Dis. Res. 12, 87-96.

\section{AUTHOR CONTRIBUTIONS}

BK conceived and designed the study. SZ, JZ, ZL, and YH contributed to the experiment. SZ and BK contributed to writing the manuscript. All authors contributed to the article and approved the submitted version.

\section{FUNDING}

This work was supported by National Basic Research Priorities Program Grant 2015CB554201 and National Science and Technology Major Project 2018ZX10714002.

Kaper, J. B., Morris, J. G.Jr., and Levine, M. M. (1995). Cholera. Clin. Microbiol. Rev. 8, 48-86. doi: 10.1128/CMR.8.1.48

Kogure, K., Simidu, U., and Taga, N. (1979). A Tentative Direct Microscopic Method for Counting Living Marine Bacteria. Can. J. Microbiol. 25, 415-420. doi: $10.1139 / \mathrm{m} 79-063$

Kotetishvili, M., Stine, O. C., Chen, Y., Kreger, A., Sulakvelidze, A., Sozhamannan, S., et al. (2003). Multilocus Sequence Typing has Better Discriminatory Ability for Typing Vibrio cholerae Than Does Pulsed-Field Gel Electrophoresis and Provides a Measure of Phylogenetic Relatedness. J. Clin. Microbiol. 41, 21912196. doi: 10.1128/JCM.41.5.2191-2196.2003

Lahteinen, T., Lindholm, A., Rinttila, T., Junnikkala, S., Kant, R., Pietila, T. E., et al. (2014). Effect of Lactobacillus Brevis ATCC 8287 as a Feeding Supplement on the Performance and Immune Function of Piglets. Vet. Immunol. Immunopathol. 158, 14-25. doi: 10.1016/j.vetimm.2013.09.002

Li, H., Bai, R., Zhao, Z., Tao, L., Ma, M., Ji, Z., et al. (2018). Application of Droplet Digital PCR to Detect the Pathogens of Infectious Diseases. Biosci. Rep. 38, 6. doi: 10.1042/BSR20181170

Li, L., Mendis, N., Trigui, H., Oliver, J. D., and Faucher, S. P. (2014). The Importance of the Viable But Non-Culturable State in Human Bacterial Pathogens. Front. Microbiol. 5, 258. doi: 10.3389/fmicb.2014.00258

Link-Lenczowska, D., Pallisgaard, N., Cordua, S., Zawada, M., Czekalska, S., Krochmalczyk, D., et al. (2018). A Comparison of qPCR and ddPCR Used for Quantification of the JAK2 V617F Allele Burden in Ph Negative MPNs. Ann. Hematol. 97, 2299-2308. doi: 10.1007/s00277-018-3451-1

Lleo, M. M., Pierobon, S., Tafi, M. C., Signoretto, C., and Canepari, P. (2000). mRNA Detection by Reverse Transcription-PCR for Monitoring Viability Over Time in an Enterococcus Faecalis Viable But Nonculturable Population Maintained in a Laboratory Microcosm. Appl. Environ. Microbiol. 66, 45644567. doi: 10.1128/AEM.66.10.4564-4567.2000

Nebe-von-Caron, G., Stephens, P. J., Hewitt, C. J., Powell, J. R., and Badley, R. A. (2000). Analysis of Bacterial Function by Multi-Colour Fluorescence Flow Cytometry and Single Cell Sorting. J. Microbiol. Methods 42, 97-114. doi: 10.1016/s0167-7012(00)00181-0

Nocker, A., Cheung, C. Y., and Camper, A. K. (2006). Comparison of Propidium Monoazide With Ethidium Monoazide for Differentiation of Live vs. Dead Bacteria by Selective Removal of DNA From Dead Cells. J. Microbiol. Methods 67, 310-320. doi: 10.1016/j.mimet.2006.04.015

Oliver, J. D. (2005). The Viable But Nonculturable State in Bacteria. J. Microbiol. $43,93-100$.

Oliver, J. D. (2010). Recent Findings on the Viable But Nonculturable State in Pathogenic Bacteria. FEMS Microbiol. Rev. 34, 415-425. doi: 10.1111/j.15746976.2009.00200.x

Pinto, D., Santos, M. A., and Chambel, L. (2015). Thirty Years of Viable But Nonculturable State Research: Unsolved Molecular Mechanisms. Crit. Rev. Microbiol. 41, 61-76. doi: 10.3109/1040841X.2013.794127

Strauber, H., and Muller, S. (2010). Viability States of Bacteria-Specific Mechanisms of Selected Probes. Cytometry A. 77, 623-634. doi: 10.1002/ cyto.a. 20920 
Sun, Y., and Joyce, P. A. (2017). Application of Droplet Digital PCR to Determine Copy Number of Endogenous Genes and Transgenes in Sugarcane. Plant Cell. Rep. 36, 1775-1783. doi: 10.1007/s00299-017-2193-1

Trevors, J. T. (2011). Viable But Non-Culturable (VBNC) Bacteria: Gene Expression in Planktonic and Biofilm Cells. J. Microbiol. Methods 86, 266273. doi: 10.1016/j.mimet.2011.04.018

Wu, B., Liang, W. L., and Kan, B. (2015). Enumeration of Viable Non-Culturable Vibrio cholerae Using Propidium Monoazide Combined With Quantitative PCR. J. Microbiol. Methods 115, 147-152. doi: 10.1016/j.mimet.2015.05.016

Wu, B., Liang, W. L., and Kan, B. (2016). Growth Phase, Oxygen, Temperature, and Starvation Affect the Development of Viable But Non-Culturable State of Vibrio cholerae. Front. Microbiol. 7, 404. doi: 10.3389/fmicb.2016.00404

Xu, H. S., Roberts, N., Singleton, F. L., Attwell, R. W., Grimes, D. J., and Colwell, R. R. (1982). Survival and Viability of Nonculturable Escherichia Coli and Vibrio cholerae in the Estuarine and Marine Environment. Microb. Ecol. 8, 313-323. doi: 10.1007/BF02010671

Xu, J., Zhang, N., Luo, M., Wang, M., Wang, L., Li, J., et al. (2021). Rapid Identification of Plasmid Replicon Type and Coexisting Plasmid-Borne Antimicrobial Resistance Genes by S1-Pulsed-Field Gel ElectrophoresisDroplet Digital Polymerase Chain Reaction. Foodborne Pathog. Dis. 18, 298305. doi: $10.1089 /$ fpd.2020.2865
Zhang, X.-H., Ahmad, W., Zhu, X. Y., Chen, J., and Austin, B. (2021). Viable But Nonculturable Bacteria and Their Resuscitation: Implications for Cultivating Uncultured Marine Microorganisms. Mar. Life Sci. Technol. 3, 189-203. doi: $10.1007 / \mathrm{s} 42995-020-00041-3$

Conflict of Interest: The authors declare that the research was conducted in the absence of any commercial or financial relationships that could be construed as a potential conflict of interest.

Publisher's Note: All claims expressed in this article are solely those of the authors and do not necessarily represent those of their affiliated organizations, or those of the publisher, the editors and the reviewers. Any product that may be evaluated in this article, or claim that may be made by its manufacturer, is not guaranteed or endorsed by the publisher.

Copyright (C) 2021 Zhao, Zhang, Li, Han and Kan. This is an open-access article distributed under the terms of the Creative Commons Attribution License (CC BY). The use, distribution or reproduction in other forums is permitted, provided the original author(s) and the copyright owner(s) are credited and that the original publication in this journal is cited, in accordance with accepted academic practice. No use, distribution or reproduction is permitted which does not comply with these terms. 